\title{
Analisis Pengaruh Struktur Kepemilikan, Ukuran dan Pertumbuhan Perusahaan terhadap Manajemen Laba pada Perusahaan BEI Tahun 2014-2018
}

\author{
Mardianto \\ Program Studi Akuntansi, Universitas Internasional Batam, mardianto.zhou@uib.ac.id, Indonesia
}

\begin{abstract}
The study was conducted with the aim of analyzing the effect of ownership structure, company size and company growth as an independent variables on earnings management as the dependent variable. Ownership structure is represented by proxies of ownership concentration, institutional ownership, family ownership, and state ownership. This study collected data with a purposive sampling method. The object of collecting data samples is in the form of data from financial reports and annual reports of companies listed on the Indonesia Stock Exchange (IDX) from 2014 to 2018. This study uses multiple regression analysis methods to examine the effect of independent variables on the dependent variable. Research data were tested using Statistical Product and Service Solutions (SPSS). The results showed that family ownership, institutional ownership and state ownership had a significant positive effect on earnings management. Ownership concentration has a significant negative effect on earnings management. Meanwhile, company size and company growth do not have a significant relationship with earnings management.
\end{abstract}

Keywords: earnings management, ownership structure, company size, company growth 


\section{Pendahuluan}

Laporan keuangan biasanya digunakan sebagai alat ukur bagi beberapa instansi keuangan eksternal seperti bank dalam menilai kelayakan ekonomi perusahaan tersebut dalam menerima pinjaman ataupun transaksi keuangan lainnya. Para pemegang saham dan investor pun mengambil informasi dari laporan keuangan dalam menilai kelayakan investasi perusahaan. Laporan keuangan merupakan gambaran dari keadaan perusahaan. Laporan keuangan yang dibuat atau dikerjakan harus bersifat transparan dan handal. Manajer dalam suatu perusahaan mempunyai tanggung jawab dalam melaporkan laporan keuangan periode tertentu kepada pihak internal maupun eksternal ketika dibutuhkan.

Manajemen laba terjadi karena manajer di dalam perusahaan mengubah penyusunan transaksi dan menggunakan judgement yang ada untuk mempengaruhi laporan keuangan perusahaan. Hal tersebut dapat membuat pihak-pihak yang berkepentingan salah mengambil keputusan mengenai nilai ekonomis perusahaan dikarenakan hasil dari laporan keuangan mempunyai hubungan dengan kontrak yang berlaku dan bergantungan dengan angka akuntansi yang terdapat dalam laporan perusahaan tersebut (Healy dan Wahlen, 1999). Hal ini berkaitan erat dengan teori keagenan.

Konflik keagenan terjadi dikarenakan terdapat perbedaan prinsip atau kepentingan dalam perusahaan antara penanam modal dengan manajer suatu perusahaan (Jensen dan Meckling, 1976). Manajemen laba sebenarnya merupakan fenomena yang susah dihindari. Hal ini dikarenakan standar akuntansi yang mengharuskan penggunaan basis akrual pada saat menyusun laporan keuangan. Penggunaan pengukuran basis akrual sangat penting untuk diamati dalam mendeteksi tindakan manajemen laba dalam suatu perusahaan.

Maraknya kasus manajemen laba mencerminkan peningkatan laporan keuangan yang dilaporkan jauh dari transparan dikarenakan sebagian manajer menggunakan tindakan manajemen laba untuk meningkatkan atau menurunkan laba perusahaan untuk kepentingan sendiri. Masalah manajemen laba semakin menjadi perhatian publik seperti munculnya beberapa kasus yang terkenal di mata publik. Contohnya PT Bank Lippo Tbk yang melakukan manipulasi laporan keuangan per tanggal 30 September 2002 dengan menyampaikan ke publik bahwa total aset perseroan sebesar Rp24triliun dan laba bersih sebesar Rp98Milyar. Akan tetapi didalam pelaporan ke Bursa Efek Jakarta (BEJ) pada tanggal 27 Desember 2002, perusahaan kemudian mengubah total aset menjadi Rp22,8triliun serta perusahaan mengalami kerugian bersih sebesar Rp1,3triliun. Pada saat itu investor ataupun nasabah menjadi kecewa dan merasa dicurangi dikarenakan telah menanamkan dananya sebelum pelaporan ke BEJ.

Lassoued, Attia, dan Sassi (2017) mengemukakan bahwa struktur kepemilikan dapat digunakan untuk mengawasi manajemen perusahaan dalam upaya menekan praktek manajemen laba. Penelitiannya mengungkapkan bahwa perusahaan yang tinggi struktur kepemilikan institusional, kepemilikan keluarga, konsentrasi kepemilikan, dan kepemilikan negara terbukti mampu menurunkan praktek manajemen laba perusahaan. Penelitian ini dilakukan untuk menguji pengaruh struktur kepemilikan dan memasukkan variabel ukuran dan pertumbuhan perusahaan terhadap manajemen laba dengan mengambil sampel data pada perusahaan yang terdaftar di Bursa Efek Indonesia (BEI) untuk kurun waktu tahun 2014 sampai dengan 2018.

\section{Kerangka Teoritis dan Perumusan Hipotesis}

Menurut Ronen dan Yaari (2008), manajemen laba adalah sekumpulan dari suatu ketetapan manajerial yang mengakibatkan manajer tidak mengungkapkan atau melaporkan laporan keuangan dalam jangka pendek dan manajer mengoptimalkan laba pada perusahaan. Manajemen laba legal jika keuntungan yang akan dilaporkan pada laporan keuangan sesuai dengan General Accepted Accounting Principle (GAAP) seperti mengubah metode untuk penyusutan dan metode untuk penilaian persediaan. Manajemen laba adalah perubahan laporan keuangan yang dilaporkan menjerumuskan penanam modal dan mempengaruhi hasil kontrak (Healy dan Wahlen, 1999). DeFond dan Francis (2005) menyimpulkan bahwa standar akuntansi mengijinkan akuntan untuk memilih pilihan yang harus dilakukan, penilaian yang dibuat, dan asumsi oleh manajer dalam menghasilkan laporan keuangan. Oleh karena itu, validitas tergantung pada asumsi peneliti dari kualitas pelaporan dan bagaimana kualitas tersebut diukur. Namun, manajemen laba dapat dilakukan jika tidak diawasi dengan tepat. Hal ini dikarenakan kesengajaan untuk mengelola laporan keuangan yang tidak tepat untuk memenuhi proyeksi yang sesuai untuk semua orang (Millstein, 2005).

Secara umum, terdapat 2 metode dalam mengendalikan manajemen laba perusahaan. Metode 
pertama adalah memanipulasi pendapatan perusahaan yang dapat mempengaruhi arus kas perusahaan. Kebijakan ini biasanya dikenal sebagai manajemen laba nyata (Roychowdhury, 2006). Praktek manajemen laba yang nyata biasanya ditempuh melalui tiga pendekatan yaitu biaya produksi, pemanipulasian arus kas dalam kegiatan operasional, dan biaya kebijakan. Metode kedua adalah memanipulasi laba dengan cara akrual. Kebijakan ini dikenal sebagai manajemen laba dengan berbasis akrual (Healy dan Wahlen, 1999). Manajemen laba berdasarkan akrual dapat didefinisikan sebagai tindakan perusahaan dalam memanipulasi kegiatan operasi perusahaan untuk mencapai tujuan perusahaan dalam meningkatkan pendapatan perusahaan (Healy dan Wahlen, 1999). Gunny (2014) menyatakan bahwa manipulasi manajemen laba berbasis akrual lebih kerap digunakan sebagai pusat observasi atau pemeriksaan oleh auditor daripada keputusan produksi dan harga dalam perusahaan. Ratmono(2010) mengungkapkan bahwa manajemen laba dengan manipulasi aktivitas yang nyata itu sulit untuk ditemukan oleh auditor.

Menurut Warfield, Wild, dan Wild (1995), manajer yang mempunyai saham dalam perusahaan dapat mengurangi dorongan untuk memanipulasi informasi akuntasi yang akan dilaporkan. Sedangkan menurut Leuz, Nanda, dan Wysocki (2003), manajemen laba tidak mampu menunjukkan keadaan perusahaan yang sebenarnya dengan demikian manajemen laba dinilai tidak bisa melindungi kepentingan investor sepenuhnya.

\section{Pengaruh Konsentrasi Kepemilikan terhadap Manajemen Laba}

Konsentrasi kepemilikan dapat menjadi sistem internal dalam kedisiplinan manajemen dengan meningkatkan efektivitas pemantauan untuk sebuah perusahaan. Hal itu disebabkan jika penanam modal saham mempunyai kepemilikan yang besar maka bisa mempunyai akses informasi yang lebih baik dalam perusahaan untuk mengimbangi keuntungan informasi yang didapat dari manajemen. Tindakan manipulasi manajemen laba dapat dikurangi jika hal tersebut dapat diwujudkan (Ooghe dan Langhe, 2012). Usman dan Yero (2012) menyimpulkan kepemilikan terkonsentrasi memiliki dampak signifikansi secara negatif dengan manajemen laba. Jika suatu perusahaan tersebut mempunyai kepemilikan terkonsentrasi yang tinggi, maka kemungkinan untuk memanipulasi laporan keuangan akan semakin kecil. Penelitian
Abdoli (2011) konsisten dengan penelitian yang dilakukan oleh Usman dan Yero (2012) yang menunjukkan bahwa kepemilikan konsentrasi berpengaruh signifikan negatif terhadap manajemen laba.

$\mathrm{H}_{1}=$ konsentrasi kepemilikan berpengaruh signifikan negatif terhadap manajemen laba.

\section{Pengaruh Kepemilikan Keluarga terhadap Manajemen Laba}

Menurut Siregar dan Utama (2008), manajemen laba lebih efisien untuk dikontrol pada perusahaan kepemilikan keluarga dibandingkan dengan perusahaan non-keluarga. Perusahaan kepemilikan keluarga akan lebih efektif dibandingkan dengan perusahaan kepemilikan publik dalam hal menjaga kualitas laporan keuangan. Kepemilikan kelurga yang efektif akan menurunkan biaya agensi (agency cost).

Richardson dan Leung (2011) dalam penelitiannya terhadap perusahaan-perusahaan di Hongkong menemukan bahwa kontrol kepemilikan keluarga mempunyai hubungan positif dalam mempengaruhi manajemen laba. Hasil penelitian mengemukakan bahwa suatu perusahaan yang dikontrol oleh kepemilikan saham keluarga mempunyai tingkat kualitas atau mutu pelaporan keuangan yang lebih tinggi dan konsisten. Perusahaan dengan kontrol kepemilikan keluarga mempunyai kemungkinan dalam keterlibatan praktek menurunkan manajemen laba.

$\mathrm{H}_{2}=$ kepemilikan keluarga berpengaruh signifikan positif terhadap manajemen laba.

\section{Pengaruh Kepemilikan Institusional terhadap Manajemen Laba}

Menurut Tarjo (2008), kepemilikan institusional merupakan kepemilikan yang merupakan suatu lembaga atau institusi yakni perusahaan asuransi, bank, dan institusi lain-lainnya. Kepemilikan institusional diukur dengan persentase kepemilikan yang dihitung pada saat akhir tahun laporan keuangan. Dalam hal ini, kepemilikan institusional mempunyai kualitas seperti keahlian, sumber daya, dan profesionalisme yang memungkinkan untuk mengoptimalkan pengawasan terhadap manajer perusahaan yang dimiliki.

Penelitian yang dilakukan Alaryan (2015) menjelaskan adanya pengaruh signifikan positif dari kepemilikan institusional terhadap manajemen laba. Penelitian tersebut menggunakan laporan tahunan 
perusahaan industri untuk periode 2009 sampai dengan 2013. Roodposhti dan Chashmi (2010) dalam penelitiannya juga membuktikan bahwa kepemilikan institusional berhubungan positif dengan manajemen laba.

$\mathrm{H}_{3}=$ kepemilikan institusional berpengaruh signifikan positif terhadap manajemen laba.

\section{Pengaruh Kepemilikan Negara terhadap Manajemen Laba}

Menurut teori berbasis sumber daya, perusahaan milik negara memiliki kelebihan dalam mengakses sumber daya, manfaat pajak, dan jaminan pada lingkungan operasi yang semuanya menambah nilai perusahaan milik negara. Namun, menurut teori agensi perusahaan milik negara memiliki beban tanggung jawab sosial dan tujuan politik seperti mempertahankan pekerjaan dan memenuhi sasaran pendapatan tahunan pada pemerintah. Karena itu, perusahaan milik negara tidak mampu untuk melakukan keputusan yang optimal dan dapat menurunkan nilai perusahaan (Wei, Xie, dan Zhang, 2005).

Wang dan Yung (2011) menunjukkan bahwa perlindungan terhadap perusahaan milik negara oleh pemerintah mengarah ke struktur insentif yang berbeda di perusahaan negara dan menghasilkan tingkat manajemen yang lebih rendah. Najid dan Rahman (2011) menemukan bahwa keterlibatan kepemilikan negara dengan perusahaan yang berkaitan dengan pemerintah dapat menunjukkan hubungan yang positif terhadap kualitas manajemen laba.

$\mathrm{H}_{4}=$ Kepemilikan negara berpengaruh signifikan positif terhadap manajemen laba.

\section{Pengaruh Ukuran Perusahaan terhadap Manajemen Laba}

Jouber dan Fakhfakh (2011) menyimpulkan jika pengukuran ukuran perusahaan dengan penggunaan the natural log of total asstes mempunyai hubungan positif pada manajemen laba. Serta, Goh, Lee, dan Cho (2016) menunjukkan hasil positif secara signifikan hubungan antara ukuran perusahaan dengan manajemen laba. Hal itu karena perusahaan yang lebih besar bisa terlibat dalam manajemen laba karena akrual diskresioner yang besar.
Hasil dari penelitian oleh Mamman et al. (2016) mengungkapkan ukuran perusahaan mendapatkan hasil yang positif dengan manajemen laba. Hasil tersebut dapat dikaitkan dengan keuntungan yang dinikmati oleh perusahaan yang lebih besar melalui skala ekonomi dan ekonomi ruang lingkup. Dengan demikian, semakin besar perusahaan berarti semakin berkualitas juga laporan keuangan perusahaan tersebut dikarenakan dapat mempekerjakan manajer dan auditor yang kompeten untuk mengaudit akunnya. Temuan ini konsisten dengan temuan Sharon (2009). $\mathrm{H}_{5}=$ Ukuran perusahaan berpengaruh signifikan positif terhadap manajemen laba.

Pengaruh Pertumbuhan Perusahaan terhadap Manajemen Laba

Lyu, Chun, Yuen, dan Zhang (2016) mengungkapkan pertumbuhan perusahaan berhubungan secara signifikan positif dengan discretionary accruals. Al-rassas dan Kamardin (2017) juga mengungkapkan relasi signifikan secara positif antara pertumbuhan perusahaan dan discretionary accruals. Dimitropoulos dan Asteriou (2010), Gul, Fung, dan Jaggi (2009), dan Sharma dan Kuang (2014) menyimpulkan bahwa pertumbuhan mempunyai hubungan positif pada manajemen laba.

$\mathrm{H}_{6}=$ Pertumbuhan perusahaan berpengaruh signifikan positif terhadap manajemen laba.

\section{Definisi Operasional Variabel dan Metode Analisis Data}

Penelitian ini menggunakan variabel kuantitatif dan bisa dikelompokkan sebagai penelitian dasar dikarenakan tujuan untuk penelitian ini yaitu untuk mengevaluasi konsep teoritis. Penelitian dasar diharapkan bisa membantu dalam pengembangan teori.

Penelitian ini bersifat kausal komparatif, dimana penelitian yang dilakukan adalah untuk mecari tahu tentang sebab akibat dari dua variabel atau lebih dengan cara berdasarkan peninjauan terhadap akibat yang terjadi lalu mencari atau menginvestigasikan kembali faktor penyebabnya dengan melalui data yang dikumpulkan (Indriantoro dan Supomo, 2002). Penelitian tersebut dilakukan dengan bertujuan untuk menganalisis apakah variabel independen yang diuji berpengaruh terhadap variabel dependen dalam penelitian ini.

Variabel Dependen: Manajemen Laba 
Definisi dari manajemen laba adalah suatu tindakan yang bisa merendahkan nilai integritas dalam laporan keuangan sehingga bisa mempengaruhi investor atau pengguna laporan keuangan yang telah percaya dengan hasil dari rekayasa tersebut (Setiawati dan Na'im, 2000). Penggunaan proksi dalam melakukan pengukuran manajemen laba adalah diskresional akrual yaitu dengan menggunakan modifed Jones model (Abdullah dan Ismail, 2016).

\section{Mengukur Total Accruals (TACC)}

$\mathrm{TACC}_{\mathrm{it}}=\mathrm{NI}_{\mathrm{it}}-\mathrm{OCF}_{\mathrm{it}}$
$\mathrm{TACC}_{\mathrm{it}} / \mathrm{TA}_{\mathrm{it}-1}={ }_{\mathrm{a} 1}\left(1 / \mathrm{TA}_{\mathrm{it}-1}\right)_{\mathrm{a}_{2} 2}\left(\Delta \mathrm{REV}_{\mathrm{it}}-\Delta \mathrm{REC}_{\mathrm{it}} /\right.$
$\left.\mathrm{TA}_{\mathrm{it}-1}\right)+{ }_{\mathrm{a} 3}\left(\Delta \mathrm{PPE}_{\mathrm{it}} / \mathrm{TA}_{\mathrm{it}-1}\right)+{ }_{\mathrm{a} 4} \mathrm{ROA}_{\mathrm{it}-1}$

Mengukur Discretionary Accruals (DAC)

$\mathrm{DAC}_{\mathrm{it}}=\mathrm{TACC}_{\mathrm{it}} / \mathrm{TA}_{\mathrm{it}-1}-\mathrm{NDAC}_{\mathrm{it}} / \mathrm{TA}_{\mathrm{it}-1}$

\section{Mengukur Non-discretionary Accruals (NDAC)}

$\mathrm{NDAC}_{\mathrm{it}}={ }_{\mathrm{a} 1}\left(1 / \mathrm{TA}_{\mathrm{it}-1}\right)+\mathrm{a}_{2}\left(\Delta \mathrm{REV}_{\mathrm{it}}-\Delta \mathrm{REC}_{\mathrm{it}} / \mathrm{TA}_{\mathrm{it}-1}\right)+$ a3 $\left(\triangle \mathrm{PPE}_{\mathrm{it}} / \mathrm{TA}_{\mathrm{it}-1}\right)+{ }_{\mathrm{a} 4} \mathrm{ROA}_{\mathrm{it}-1}$

\section{Variabel Independen: Konsentrasi Kepemilikan}

Konsentrasi kepemilikan yaitu kepemilikan dari pihak eksternal perusahaan yang diukur menggunakan persentase saham yang didapatkan dari sebagian kecil perseorangan maupun kelompok. Rumus perhitungan konsentrasi kepemilikan menurut Grimaldi dan Muserra (2017) adalah:

Persentase kepemilikan saham yang dimiliki oleh pemegang saham setidaknya terdapat $2 \%$ dari saham biasa perusahaan $\mathrm{i}$ untuk periode $\mathrm{t}$.

\section{Variabel Independen: Kepemilikan Keluarga}

Kepemilikan keluarga yaitu kepemilikan saham dalam suatu organisasi ataupun perusahaan yang dimiliki anggota keluarga. Dimana kepemilikan ini melibatkan anggota keluarga dalam melakukan berbagai kegiatan operasional yang ada pada perusahaan. Rumus perhitungan kepemilikan keluarga menurut (Darmadi, 2016) adalah:

$\frac{\text { \% Jumlah saham kepemilikan keluarga }}{\text { Jumlah saham yang beredar }}$

Variabel Independen: Kepemilikan Institusional
Kepemilikan institusional yaitu kepemilikan pemegang saham dalam suatu perusahaan yang terdiri dari sebuah institusi maupun lembaga. Perumusan kepemilikan institusional menggunakan jumlah saham yang dipegang oleh investor institusi. Rumus perhitungan kepemilikan institusional menurut Susanto dan Pradipta (2016) adalah:

\section{\% Jumlah saham kepemilikan institusional} Jumlah saham yang beredar

\section{Variabel Independen: Kepemilikan Negara}

Kepemilikan negara dapat memberikan manfaat seperti hak istimewa seperti subsidi langsung dan perlakuan dengan pengaturan khusus. Kerangka hukum dapat mempengaruhi hubungan antara kepemilikan negara dan tata kelola perusahaan. Rumus perhitungan kepemilikan negara menurut Ali, Qiang, dan Ashraf (2018) adalah:

$\frac{\text { \% Jumlah saham kepemilikan negara }}{\text { Jumlah saham yang beredar }}$

\section{Variabel Independen: Ukuran Perusahaan}

Ukuran perusahaan merupakan kecil atau besarnya standar entitas yang dinilaikan berdasarkan dengan nilai total aset. Ukuran perusahaan biasanya dikelompokkan dengan beberapa kelompok seperti ukuran perusahaan yang besar, kecil dan sedang. Proksi dalam mengukur ukuran perusahaan menurut Roodposhti dan Chashmi (2010) adalah:

Nilai logaritma dari total aset

Variabel Independen: Pertumbuhan Perusahaan

Pertumbuhan perusahaan yaitu tolak ukur mengenai keberhasilan perusahaan dalam melakukan investasi untuk pertumbuhan perusahaan dimasa mendatang. Proksi yang digunakan untuk mengukur pertumbuhan perusahaan menurut Mehrani, Moradi, dan Eskandar (2017) adalah:

Nilai pasar per saham Nilai buku persaham 


\section{Statistik Deskriptif}

Penelitian kuantitatif ini teknik menganalisa datanya menggunakan statistik deskriptif berfungsi dalam melakukan analisis data untuk mengambarkan atau mendeskripsikan data yang telah terkumpul bermaksud untuk mudah dipahami dan dapat diinterprestasikan dikarenakan hasil yang terkumpul terbentuk dari tabulasi (Sugiyono, 2013). Teknik dari analisis ini dapat memberikan informasi umum mengenai cara penyajian data dan memberi penjelasan mengenai data yang akan dilakukan pengujian. Contohnya seperti nilai maksimum, jumlah data, nilai minimun, dan juga standard deviasi yang terdapat didalam setiap variabel untuk data non kategori.

\section{Regresi Panel}

Terdapat 3 metode yang biasa digunakan untuk regresi panel, antara lain:

a. Pooled Least Square (PLS) yaitu teknik agar bisa mengestimasikan model data panel.

b. Fixed Effect Model (FEM) mengasumsikan bahwa slop ataupun intersep dari masing-masing individu dan waktu adalah berbeda dan bersifat tetap.

c. Random Effect Model (REM) mengasumsikan bahwa untuk setiap perusahaan terdapat intersep yang berbeda, dimana merupakan variabel stokastik atau random.

\section{Pemilihan Model Terbaik}

Pemilihan dalam model yang terbaik pada regresi panel antara PLS, FEM, dan REM dilakukan dengan menerapkan 2 teknik dari estimasi model. Dua teknik tersebut yaitu memakai statistik uji Chow dan uji Hausman.

Uji Chow dilakukan agar dapat memastikan apakah model pooled least square dengan fixed effect model yang akan digunakan. Model regresi layak menggunakan FEM jika nilai signifikan melebihi 0,05 dikarenakan penggunaan FEM dinilai paling tepat dalam memprediksikan variabel dependen. Namun jika hasil menunjukkan sebaliknya maka model regresi yang layak adalah pooled least squares (Ariefianto, 2012).

Uji Hausman yang dilakukan agar dapat menemukan antara model fixed effect atau random effect yang layak. Dimana pengujian dengan Hausman menganalisis hasil seperti Chi Square dengan ketentuan jika nilai Chi Square dibawah 0,05 maka model yang layak adalah fixed effect model. Sebaliknya, jika nilai diatas 0,05 maka model yang layak adalah random effect model (Ariefianto, 2012).

\section{Uji Hipotesis}

Tujuan dari pengujian hipotesis yaitu agar dapat memahami seberapa besar kontribusi untuk masingmasing variabel yang terpengaruh (Ariefianto, 2012). Uji hipotesis dalam penelitian umumnya berupa uji $\mathrm{F}$, uji t, dan uji Goodnes of Fit Model.

Menurut Ghozali (2011), uji F bertujuan untuk membuktikan pengaruh dari variabel independen terhadap dependen secara simultan. Kriteria dalam uji F sebagai berikut:

a. Jika nilai dari probabilitas melebihi 0,05 maka variabel independen tidak berpengaruh secara simultan terhadap dependen.

b. Jika nilai dari probabilitas dibawah 0,05 maka variabel independen berpengaruh secara simultan dengan dependen.

Uji t memperlihatkan kesesuaian parameter dengan hipotesis antara pengaruh dari variabel independen secara individual terhadap variabel dependen. Kriteria uji $\mathrm{t}$ dilihat dari nilai signifikansi. Jika nilai signifikansi dibawah 0,05 , maka variabel independen tersebut berpengaruh signifikan terhadap variabel dependen dan sebaliknya.

Uji goodness of fit model digunakan untuk menguji kecocokan dari mode regresi yang dihasilkan pada regresi panel. $\mathrm{R}^{2}$ dapat menjelaskan seberapa besarnya perubahan ataupun variasi dalam sebuah variabel dapat dijelaskan oleh variasi ataupun perubahan dalam variabel yang lain (Ashari dan Santoso, 2005). Apabila nilai $\mathrm{R}^{2}$ tinggi maka semakin tinggi independen bisa menjelaskan variabel dependen namun, jika nilai $\mathrm{R}^{2}$ menunjukkan hasil yang kecil maka sebaliknya (Ghozali, 2011).

\section{Analisis dan Pembahasan}

\section{Statistik Deskriptif}

Data pada penelitian ini berupa data sekunder yang menggunakan laporan tahunan dan laporan keuangan perusahaan-perusahaan yang terdaftar pada Bursa Efek Indonesia (BEI) sejak tahun 2014 sampai dengan 2018. Jumlah sampel yang digunakan adalah 400 perusahaan. Pada penelitian ini setiap perusahaan diobservasi dalam empat tahun sehingga total keseluruhan data yang digunakan untuk diuji adalah 2000 data. Terdapat data yang menyimpang sebanyak 
312 data, sehingga total data yang terdapat didalam penelitian menjadi 1688 data.

Tabel 1

Hasil Statistik Deskriptif

\begin{tabular}{lcllcc}
\hline \multicolumn{1}{c}{ Variabel } & $\mathbf{N}$ & Minimum & Maksimum & $\begin{array}{c}\text { Rata- } \\
\text { Rata }\end{array}$ & SD \\
\hline $\begin{array}{l}\text { Konsentratsi } \\
\text { Kepemilikan }\end{array}$ & 1688 & 0,0000 & 0,998 & 0,719 & 0,1777 \\
$\begin{array}{l}\text { Kepemilikan } \\
\text { Keluarga }\end{array}$ & 1688 & 0,0000 & 0,986 & 0,463 & 0,3138 \\
$\begin{array}{l}\text { Kepemilikan } \\
\text { Institusional }\end{array}$ & 1688 & 0,0000 & 0,998 & 0,624 & 0,2573 \\
$\begin{array}{l}\text { Kepemilikan } \\
\text { Negara }\end{array}$ & 1688 & 0,0000 & 0,900 & 0,033 & 0,1417 \\
$\begin{array}{l}\text { Ukuran } \\
\text { Perusahaan }\end{array}$ & 1688 & 1,41 & 444,71 & 9,868 & 23,382 \\
$\begin{array}{l}\text { Pertumbuhan } \\
\text { Perusahaan }\end{array}$ & 1688 & 0,0002 & 5590,00 & 32,59 & 245,36 \\
$\begin{array}{l}\text { Manajemen } \\
\text { Laba }\end{array}$ & 1688 & $-0,1660$ & 0,107 & $-0,027$ & 0,0590 \\
\hline $\begin{array}{l}\text { Sumber : Data penelitian diolah (2020) } \\
\text { Mumber }\end{array}$ & & & & & \\
\hline
\end{tabular}

Uji Chow

Tabel 2

Hasil Uji Chow

\begin{tabular}{lll}
\hline Effect Test & Prob. & Kesimpulan \\
\hline $\begin{array}{l}\text { Cross Section Chi- } \\
\text { square }\end{array}$ & 0,0000 & Fixed Effect Model
\end{tabular}

Sumber : Data penelitian diolah (2020)

Tabel 2 memperlihatkan hasil dari nilai probabilitas senilai 0,0000. Jadi metode yang dipilih merupakan Fixed Effect Model. Maka penelitian ini berlanjut dengan metode uji hausman.

\section{Uji Hausman}

Tabel 3

Hasil Uji Hausman

\begin{tabular}{lll}
\hline Effect Test & Prob. & Kesimpulan \\
\hline $\begin{array}{l}\text { Cross Section } \\
\text { Random }\end{array}$ & Random Effect Model \\
\hline Sumber : Data penelitian diolah (2020) &
\end{tabular}

Dilihat dari Tabel 3 diatas, dapat diamati bahwa hasil probabilitas menunjukkan angka sebesar 0,2377 yang artinya dalam pengujian ini, pola yang akan digunakan yaitu Random Effect Model karena hasilnya lebih dari 0,05 .

Uji F
Pengujian $\mathrm{F}$ bertujuan untuk mendeteksi apakah semua variabel independen mempunyai pengaruh terhadap variabel dependen secara simultan. Berikut ini adalah hasil penelitian uji $\mathrm{F}$ yaitu:

\begin{tabular}{lll}
\multicolumn{3}{c}{$\begin{array}{c}\text { Tabel } 4 \\
\text { Hasil Uji F }\end{array}$} \\
\hline $\begin{array}{l}\text { Variabel } \\
\text { Dependen }\end{array}$ & Sig. & Kesimpulan \\
\hline Manajemen Laba & 0,023835 & Signifikan \\
\hline Sumber : Data penelitian diolah (2020) &
\end{tabular}

Tabel 4 diatas menunjukkan bahwa variabel konsentrasi kepemilikan, kepemilikan keluarga, kepemilikan institusional, kepemilikan negara, ukuran perusahaan dan pertumbuhan perusahaan secara simultan berpengaruh signifikan terhadap manajemen laba. Hal ini berarti model regresi dalam penelitian bisa dipakai untuk memprediksikan faktor-faktor yang dapat mempengaruhi variabel manajemen laba.

Uji $t$

Uji t bertujuan untuk menguji pengaruh setiap variabel independen terhadap variabel dependen. Hasil uji t yang dilakukan dengan metode REM disajikan dalam tabel berikut ini:

Tabel 5

Hasil Uji $t$

\begin{tabular}{|c|c|c|c|c|}
\hline Variabel & Koefisien & Sig. & Kesimpulan & Hipotesis \\
\hline $\mathrm{C}($ Constant $)$ & $-0,03772$ & 0,3037 & & \\
\hline Konsentrasi & $-0,04089$ & 0,0124 & Signifikan & Terbukti \\
\hline Kepemilikan & & & Negatif & \\
\hline $\begin{array}{l}\text { Kepemilikan } \\
\text { Keluarga }\end{array}$ & 0,020412 & 0,0031 & $\begin{array}{l}\text { Signifikan } \\
\text { Positif }\end{array}$ & Terbukti \\
\hline $\begin{array}{l}\text { Kepemilikan } \\
\text { Institusional }\end{array}$ & 0,034124 & 0,0024 & $\begin{array}{l}\text { Signifikan } \\
\text { Positif }\end{array}$ & Terbukti \\
\hline $\begin{array}{l}\text { Kepemilikan } \\
\text { Negara }\end{array}$ & 0,041601 & 0,0286 & $\begin{array}{l}\text { Signifikan } \\
\text { Positif }\end{array}$ & Terbukti \\
\hline $\begin{array}{l}\text { Ukuran } \\
\text { Perusahaan }\end{array}$ & 0,000633 & 0,8210 & $\begin{array}{l}\text { Tidak } \\
\text { Signifikan }\end{array}$ & $\begin{array}{l}\text { Tidak } \\
\text { terbukti }\end{array}$ \\
\hline $\begin{array}{l}\text { Pertumbuhan } \\
\text { Perusahaan }\end{array}$ & 7.615464 & 0,3679 & $\begin{array}{l}\text { Tidak } \\
\text { Signifikan }\end{array}$ & $\begin{array}{l}\text { Tidak } \\
\text { terbukti }\end{array}$ \\
\hline
\end{tabular}

1. Hasil Pengujian $\mathrm{H}_{1}$

Tabel 5 diatas menunjukkan nilai signifikansi konsentrasi kepemilikan sebesar 0,0124. Hal tersebut berarti bahwa konsentrasi kepemilikan berpengaruh signifikan terhadap manajemen laba. Hasil koefisien yang menunjukkan nilai $-0,0408$ mengindikasikan bahwa konsentrasi kepemilikan dan manajemen laba memiliki hubungan 
signifikan negatif. Hasil ini menunjukkan bahwa $\mathrm{H}_{1}$ terbukti dimana jika suatu perusahaan mempunyai konsentrasi kepemilikan yang tinggi maka kualitas laporan keuangan akan lebih terjaga dan manajer cenderung tidak mempunyai ruang untuk melakukan tindakan manipulasi laba $(\operatorname{Rad} e t$ al., 2016).

2. Hasil Pengujian $\mathrm{H}_{2}$

Tabel 5 diatas menunjukkan nilai signifikansi kepemilikan keluarga sebesar 0,0031. Hal tersebut berarti bahwa kepemilikan keluarga berpengaruh signifikan terhadap manajemen laba. Hasil koefisien yang menunjukkan nilai 0,0204 mengindikasikan bahwa kepemilikan keluarga dan manajemen laba memiliki hubungan signifikan positif. Hasil ini menunjukkan bahwa $\mathrm{H}_{2}$ terbukti dimana praktek manajemen laba cenderung meningkat dikarenakan mayoritas saham perusahaan dimiliki oleh kepemilikan keluarga sehingga pihak keluarga pemilik perusahaan mempunyai hak dan akses lebih luas untuk mengelola dan memanipulasi laba pada perusahaan supaya laporan keuangan di perusahaan yang dipimpinnya kelihatan bagus (Alaryan, 2015).

3. Hasil Pengujian $\mathrm{H}_{3}$

Tabel 5 diatas menunjukkan nilai signifikansi kepemilikan institusional sebesar 0,0024. Hal tersebut berarti bahwa kepemilikan institusional berpengaruh signifikan terhadap manajemen laba. Hasil koefisien yang menunjukkan nilai 0,0034 mengindikasikan bahwa kepemilikan institusional dan manajemen laba memiliki hubungan signifikan positif. Hasil ini menunjukkan bahwa $\mathrm{H}_{3}$ terbukti dimana apabila kepemilikan institusional semakin tinggi, maka perusahaan tersebut akan memiliki tingkat manajemen laba yang tinggi. Hal tersebut dikarenakan kepemilikan saham institusional cenderung kurang aktif dalam melakukan pemantauan yang efektif dalam suatu perusahaan. Sehingga hal tersebut dapat meningkatkan praktek pemanipulasian laba perusahaan (Roodposhti \& Chashmi, 2010).

4. Hasil Pengujian $\mathrm{H}_{4}$

Tabel 5 diatas menunjukkan nilai signifikansi kepemilikan negara sebesar 0,0286. Hal tersebut berarti bahwa kepemilikan negara berpengaruh signifikan terhadap manajemen laba. Hasil koefisien yang menunjukkan nilai 0,0416 mengindikasikan bahwa kepemilikan negara dan manajemen laba memiliki hubungan signifikan positif. Hasil ini menunjukkan bahwa $\mathrm{H}_{4}$ terbukti. Ben-Nasr et al.(2015) berpendapat bahwa kepemilikan negara memiliki insentif yang lebih tinggi dalam keterlibatan untuk melakukan praktik manajemen laba dikarenakan bertujuan secara politik dalam upaya memaksimalkan laba.

5. Hasil Pengujian $\mathrm{H}_{5}$

Tabel 5 diatas menunjukkan nilai signifikansi ukuran perusahaan sebesar 0,8210 . Hal tersebut berarti bahwa ukuran perusahaan tidak berpengaruh signifikan terhadap manajemen laba. Hasil koefisien yang menunjukkan nilai 0,000633 mengindikasikan bahwa ukuran perusahaan dan manajemen laba memiliki hubungan signifikan positif. Hasil ini menunjukkan bahwa $\mathrm{H}_{5}$ tidak terbukti.

6. Hasil Pengujian $\mathrm{H}_{6}$

Tabel 5 diatas menunjukkan nilai signifikansi ukuran perusahaan sebesar 0,3679. Hal tersebut berarti bahwa pertumbuhan perusahaan tidak berpengaruh signifikan terhadap manajemen laba. Hasil koefisien yang menunjukkan nilai 7,6154 mengindikasikan bahwa pertumbuhan perusahaan dan manajemen laba memiliki hubungan signifikan positif. Hasil ini menunjukkan bahwa $\mathrm{H}_{6}$ tidak terbukti.

\section{Uji of Goodness Fit Model}

Tabel 6

Hasil Uji Goodness of Fit Model

\begin{tabular}{cc}
\hline Variabel Dependen & Adjusted $\boldsymbol{R}$ Square \\
\hline Manajemen Laba & 0,005084 \\
\hline Sumber : Data penelitian diolah (2020) &
\end{tabular}

Hasil dari tabel 6 diatas menunjukkan bahwa pengujian dengan menggunakan Goodness of Fit Model memperlihatkan nilai Adjusted $R$ Square untuk model penelitian sebesar 0,005084 atau $0,50 \%$. Artinya variabel independen yakni kepemilikan keluarga, konsentrasi kepemilikan, kepemilikan institusional, kepemilikan negara, ukuran perusahaan, dan pertumbuhan perusahaan mampu menjelaskan variabel dependen yaitu manajemen laba sebanyak $0,50 \%$. Sedangkan sisanya sebanyak $99,5 \%$ dijelaskan oleh variabel lainnya yang tidak dijadikan sebagai variabel independen dalam penelitian ini. 


\section{Kesimpulan, Keterbatasan dan Saran}

Penelitian ini dilakukan untuk menganalisis pengaruh struktur kepemilikan, ukuran perusahaan, dan pertumbuhan perusahaan terhadap manajemen laba. Struktur kepemilikan diwakilkan oleh konsentrasi kepemilikan, kepemilikan keluarga, kepemilikan institusional, dan kepemilikan negara. Kesimpulan dari penelitian menunjukkan bahwa struktur kepemilikan berperan penting dalam mempengaruhi praktek manajemen laba pada perusahaan yang terdaftar di BEI. Perusahaan yang kepemilikannya terkonsentrasi terbukti lebih mampu menurunkan aktivitas manajemen laba pada perusahaannya. Kepemilikan yang didominasi keluarga, institusional maupun negara ternyata menyebabkan praktek manajemen laba cenderung meningkat. Penelitian ini tidak menemukan hubungan yang signifikan antara ukuran dan pertumbuhan perusahaan dengan manajemen laba.

Keterbatasan dalam penelitian ini terletak pada rentang waktu penelitian dan objek penelitian yang tidak luas. Penelitian ini hanya mengambil objek penelitian dari perusahaan yang terdaftar di BEI sejak tahun 2014 sampai dengan tahun 2018. Penelitian selanjutnya diharapkan dapat memperluas objek penelitian dan memperpanjang rentang waktu objek penelitian. Pengambilan data hanya terbatas pada data sekunder berupa laporan keuangan dan laporan tahunan yang dipublikasi. Penelitian selanjutnya diharapkan dapat mengambil sampel data primer yang bersumber dari kuesioner ataupun hasil wawancara. Penelitian ini menghasilkan nilai adjusted $R$-Square yang sangat rendah (hanya sebesar $0,5 \%$ ). Penelitian selanjutnya diharapkan bisa memasukkan lebih banyak variabel independen lainnya untuk dianalisis pengaruhnya terhadap manajemen laba.

\section{Daftar Pustaka}

Abdoli, M. R. (2011). Relation of non-executive directors and ownership concentration with discretionary accrual accounting. International Academic Journal of Economics, 1(4).

Abdullah, S. N., \& Ismail, K. N. I. K. (2016). Women directors, family ownership and earnings management in Malaysia. Asian Review of Accounting, 24(4), 525-550.

Al-rassas, A. H., \& Kamardin, H. (2017). Directors' independence, internal audit function, ownership concentration and earning quality in Malaysia. Canadian Center of Science and Education, 11(15), 244-256.
Alaryan, L. A. (2015). Relationship between ownership structure and earnings quality, 4(October), 200-205.

Ali, A., Qiang, F., \& Ashraf, S. (2018). Regional dynamics of ownership structure and their impact on firm performance and firm valuation: A case of Chinese listed companies. Review of International Business and Strategy, 28(1), 128-146.

Alves, S. (2012). Ownership structure and earnings management: Evidence from Portugal. Ownership Structure and Earnings Management: Evidence from Portugal, 6.

Ben-Nasr, H., Boubakri, N., \& Cosset, J. C. (2015). Earnings quality in privatized firms: The role of state and foreign owners. Journal of Accounting and Public Policy, 34(4), 392-416.

Darmadi, S. (2016). Asian review of accounting ownership concentration, family control, and auditor choice: Evidence from an emerging market ownership concentration, family control, and auditor choice evidence from an emerging market. Asian Review of Accounting, 24(1), 19-42.

DeFond, M. L., \& Francis, J. R. (2005). Audit research after Sarbanes-Oxley. Auditing: A Journal of Pratice \& Theory, 24(SUPPL.), 5-30.

Dimitropoulos, P. E., \& Asteriou, D. (2010). The effect of board composition on the informativeness and quality of annual earnings: Empirical evidence from Greece. Research in International Business and Finance, 24(2), 190-205.

Fan, G., \& Hope, N. C. (2013). The role of state-owned enterprises in the Chinese economy. US-China 2022: Economic Relations in the Next 10 Years, 355-375.

Goh, J., Lee, J., \& Cho, J. (2016). A new relationship between ownership-control wedge and overinvestment practices: Evidence from Korean Business Groups (Chaebol). Asia-Pacific Journal of Financial Studies, 45(2), 222-253.

Grimaldi, F., \& Muserra, A. L. (2017). The effect of the ownership concentration on earnings management: Empirical evidence from the Italian context. Corporate Ownership and Control, 14(3), 236248.

Gul, F. A., Fung, S. Y. K., \& Jaggi, B. (2009). Earnings quality: Some evidence on the role of auditor tenure and auditors' industry expertise. Journal of Accounting and Economics, 47(3), 265-287.

Harahap, S. S. (2009). Analisis kritis laporan keuangan (Cetakan ke). Jakarta: Raja Grafindo Persada.

Hashim, H. A., \& Devi, S. S. (2014). Corporate governance , ownership structure and earnings quality: Malaysian evidence, (July 2014).

Healy, P. P. M., \& Wahlen, J. M. J. (1999). A review of the earnings management literature and its implications for standard setting. 
American Accounting Association Accounting Horizons, 13(4), 365-383.

Indriantoro, N., \& Supomo. (2002). Metodologi penelitian bisnis untuk akuntansi dan manajemen. In Edisi Pertama. Yogyakarta: BPFE.

Jensen, \& Meckling. (1976). Theory of the firm: managerial behavioragency and ownership structure. Journal of Financial Economics, 3, 305-360.

Jouber, H., \& Fakhfakh, H. (2011). Earnings management and board oversight: An international comparison. Managerial Auditing Journal, 27(1), 66-86.

Lassoued, N., Attia, M., \& Sassi, H. (2017). Earnings management and ownership structure in emerging market: Evidence from banking industry. Managerial Finance, 43(10), 1117-1136.

Leuz, C., Nanda, D., \& Wysocki, P. D. (2003). Earnings management and investor protection: An international comparison. Journal of Financial Economics, 69(3), 505-527.

Lyu, C., Chun, D., Yuen, Y., \& Zhang, X. (2016). Individualistcollectivist culture, ownership concentration and earnings quality, 1625(January), 1608-1625.

Mamman, S., Kurfi, B. U., Audi, A. M., Amos, B., \& Ahmad, A. A. (2016). Institutional ownership and earning quality : Evidence from quoted food/beverages and Tabacco firm in Nigeria. Nigerian Journal of Management Technology \& Development, 7(1).

Mehrani, S., Moradi, M., \& Eskandar, H. (2017). Institutional ownership type and earnings quality: Evidence from Iran. Emerging Markets Finance and Trade, 53(1), 54-73.

Najid, N. A., \& Rahman, R. A. (2011). Government ownership and performance of Malaysian government-linked companies. International Research Journal of Finance and Economics, 61(61), 42-56.

Ooghe, H., \& Langhe, T. (2012). The Anglo-American versus the Continental European corporate governance model: Empirical evidence of board composition in Belgium. European Business Review, 14(6), 437-449.

Rad, S. E. M., Salehi, D. H., \& Pour, D. H. V. (2016). A study of the interaction of audit quality and ownership structure on earning management of listed firms on Tehran Stock Exhange. International Journal of Humanities and Cultural Studies, 1596-1606.

Ratmono, D. (2010). Manajemen laba rill dan berbasis akrual: Dapatkah auditor yang berkualitas mendeteksinya? Universitas Ponegoro, 1, 1-23.

Richardson, G., \& Leung, S. (2011). Family ownership control and earnings management: Evidence from Hong Kong firms. Corporate Ownership and Control, 8(4 A), 96-111.
Ronen, J., \& Yaari, V. (2008). Earnings management: Emerging insights in theory, practice, and research. International Journal of Accounting, 46(2), 236-237.

Roodposhti, F. R., \& Chashmi, S. a N. (2010). The effect of board composition and ownership concentration on earnings management : Evidence from IRAN. Engineering and Technology, 4(6), 165-171.

Roychowdhury, S. (2006). Earnings management through real activities manipulation. Journal of Accounting and Economics.

Scott, W. R. (2009). Financial accounting theory (Fifth Edit). Canada Prentice Hall.

Sharma, V. D., \& Kuang, C. (2014). Voluntary audit committee characteristics, incentives, and aggressive earnings management: Evidence from New Zealand. International Journal of Auditing, 18(1), 76-89.

Sharon, P. K. (2009). Earnings quality and ownership structure: The role of private equity sponsors. The Accounting Review (Vol. 84).

Siregar, S. V., \& Utama, S. (2008). Type of earnings management and the effect of ownership structure, firm size, and corporategovernance practices: Evidence from Indonesia. International Journal of Accounting, 43(1), 1-27.

Stice, Stice, J., \& Skousen, F. (2009). Akuntansi keuangan menegah. Salemba Empat (Edisi 16,). Jakarta.

Sugiyono. (2016). Metodologi penelitian kuantitatif, kualitatif, dan R\&D. Alfabeta , Bandung.

Sun, Tong, W., \& Yu, Q. (2002). Determinants of foreign direct investment across China. Journal of International Money and Finance.

Susanto, Y., \& Pradipta, A. (2016). Corporate governance and real earnings management. Academy of Accounting \& Financial Studies Journal, 12(1), 9-22.

Tarjo. (2008). Pengaruh kosentrasi kepemilikan institusional dan leverage terhadap manajemen laba, nilai pemegang saham serta cost of equity capital. Universitas Trunojoyo Bangkalan Madura.

Usman, S. H., \& Yero, J. I. (2012). Ownership concentration and earning management practice of Nigerian Listed Conglomerates. American International Journal of Contemporary Research, 2(7), 157-171.

Wang, \& Yung, K. (2011). Do state enterprises manage earnings more than privately owned firms? The case of China. Journal of Business Finance and Accounting, 38(7-8), 794-812. 
Warfield, T. D., Wild, J. J., \& Wild, K. L. (1995). Managerial ownership, accounting choices, and informativeness of earnings. Journal of Accounting and Economics, 20(1), 61-91.
Wei, Z., Xie, F., \& Zhang, S. (2005). Ownership structure and firm value in China's privatized firms : 1991-2001. Journal of Financial and Quantitative Analysis, 40(01), 87.

Winanda. (2009). Analisis pengaruh independensi, kualitas audit, serta mekanisme corporate governance terhadap integritas laporan keuangan. Simposum Nasional Akuntansi, VI. 